\begin{tabular}{l}
\hline MATAPPA: Jurnal Pengabdian Kepada Masyarakat \\
Volume 2 | Nomor $2 \mid$ Maret |2019 \\
e-ISSN: 2614-6673 dan p-ISSN: $2615-5273$ \\
\begin{tabular}{|l|l|} 
(c) (1) This work is licensed under a Creative Commons Attribution \\
4.0 International License
\end{tabular}
\end{tabular}

\title{
Penerapan Pelatihan Siap Siaga Bencana (Sigana) Dalam Meningkatkan Kesiapsiagaan Bencana Pada Pecalang
}

\section{Ida Ayu Agung Laksmi', Putu Wira Kusuma Putra², I Kadek Artawan ${ }^{3}$}

\author{
Keywords : \\ disaster, preparedness, \\ disaster preparedness \\ training

\section{Kata Kunci:} \\ bencana, kesiapsiagaan, \\ pelatihan siap siaga \\ bencana

\section{Corespondensi Author \\ ${ }^{1)}$ STIKES Bina Usada Bali. \\ Jalan Padang Luwih Dalung, \\ Bali. \\ Email: \\ agunglaksmi41@gmail.com}

\section{History Artikel}

Received: tgl-bln-thn; Reviewed: tgl-bln-thn Revised: tgl-bln-thn Accepted: tgl-bln-thn Published: tgl-bln-thn

\begin{abstract}
Abstrak. Setiap Desa di Bali, memiliki satuan penjaga keamaan yang disebut sebagai Pecalang. Sebagai penjaga keamanan masyarakat, Pecalang tentunya harus dibekali pelatihan siap siaga bencana sebagai upaya dalam meningkatkan kesiapsiagaan bencana. Oleh karena itu, perlu dilakukan Pelatihan Siap Siaga Bencana (SIGANA) pada pecalang Desa Selat Badung. Pelatihan ini merupakan jenis pengabdian masyarakat dengan menggunakan pendekatan kuantitatif untuk mengukur tingkat kesiapansiagaan peserta dalam menghadapi bencana di Badung dengan menggunakan desain penelitian pre-eksperimental yaitu One Groups Pretest-Posttest Design untuk mengukur keefektivan program pelatihan SIGANA. Analisis data yang digunakan adalah dengan uji paired T-test dengan hasil didapatkan perbedaan yang signifikan antara nilai pretest dan post-test kesiapsiagaan pada 25 orang peserta pelatihan SIGANA dengan nilai $p<0.001$. Berdasarkan hasil tersebut, maka dapat disimpulkan bahwa pelatihan SIGANA efektif dalam meningkatkan kesiapsiagaan bencana pada pecalang Desa Selat, Badung. Oleh karena itu, untuk mendukung berdirinya Desa Tangguh Bencana, perlu dilakukan pelatihan-pelatihan keben-canaan yang rutin pada seluruh lapisan masyarakat.
\end{abstract}

\begin{abstract}
Every village in Bali has a security guard unit called Pecalang. As a community security guard, Pecalang certainly must be equipped with disaster preparedness training as an effort to improve disaster preparedness. Therefore, it is necessary to conduct Disaster Preparedness Training (SIGANA) in Pecalang Selat Village, Badung. This training is a type of community service using a quantitative approach to measure the level of participant preparedness in dealing with disasters in Badung by using a preexperimental with One Groups Pretest-Posttest design to measure the effectiveness of the SIGANA training program. The data analysis used was a paired T-test with the results obtained significant differences between the value of pre-test and post-test preparedness in 25 SIGANA training participants with a value of $p<0.001$. Based on these results, it can be concluded that the SIGANA training is effective in increasing disaster preparedness in the village of Selat Village, Badung. Therefore, to support the establishment of Tangguh Bencana Village, routine disaster training needs to be carried out at all levels of society.
\end{abstract}




\section{PENDAHULUAN}

Kesiapsiagaan terhadap bencana merupakan faktor yang sangatlah penting untuk meminimalisir korban. Akan tetapi, sikap kesiapsiagaan terhadap bencana belum menyeluruh pada seluruh masyarakat di Indonesia. Dalam Indriasari (2016), dikatakan bahwa salah satu peristiwa bencana gempa bumi yang terjadi di Jogjakarta mendapati jumlah korban mencapai 5.716 orang tewas dan membuat banyak orang terperangkap di dalam rumah khususnya anak-anak dan orang tua karena terjadi di pagi hari sehingga mayoritas korban merupakan orang yang berusia lanjut dan anak-anak yang kemungkinan tidak sempat menyelamatkan diri ketika gempa belangsung. Hal ini memperlihatkan masih lemahnya kesiapsiagaan menghadapi bencana di Indonesia.

Berdasarkan hasil Indeks Risiko Bencana Indonesia (IRBI) tahun 2013 yang diterbitkan oleh BNPB, dari jumlah 497 kabupaten/kota, terdapat 388 kabupaten/kota dengan risiko tinggi, sedangkan 109 kabupaten/kota dengan risiko sedang. Kabupaten Badung berdasarkan pemetaan masuk dalam wilayah yang berisiko tinggi terhadap bencana alam. Ada tiga bencana alam yang sangat rawan di wilayah ini, yakni longsor, angin kencang, maupun banjir/tsunami.

Undang-Undang Nomor 24 Tahun 2007 tentang Penanggulangan Bencana mengamanatkan pada pasal 35 dan 36 agar setiap daerah dalam upaya penanggulangan bencana, mempunyai perencanaan penanggulangan bencana. Secara lebih rinci disebutkan di dalam Peraturan Pemerintah Nomor 21 Tahun 2008 tentang Penyelenggaraan Penanggulangan Bencana. Oleh karena itu, Kabupaten Badung membentuk Desa Tangguh Bencana. Desa Tangguh Bencana merupakan desa yang memiliki kemampuan mandiri untuk beradaptasi dan menghadapi ancaman bencana, serta memulihkan diri dengan segera dari dampak bencana yang merugikan jika terkena bencana. Sebagai upaya dalam mendukung program pemerintah dalam pembentukan Desa Tangguh Bencana yang ditargetkan pada tahun 2021, perlu dilakukan pelatihan siap siaga bencana pada masyarakat kabupaten Badung.

Desa Selat, Kecamatan Abiansemal Kabupaten Badung merupakan salah satu Desa yang terletak di wilayah Badung Utara dengan jumlah penduduk $654 \mathrm{KK}$ yang dibagi mejadi 4 banjar yaitu Banjar Selat, Selat Anyar, Tegal dan Mekar Sari. Berdasarkan letak geografis, Desa Selat termasuk ke dalam wilayah dengan ancaman bencana seperti longsor dan gempa bumi. Selain itu, pada bulan September 2017, Kecamatan Abiansemal termasuk Desa Selat menjadi tempat pengungsian sekitar 1.011 orang masyarakat yang berada di kawasan rawan Bencana erupsi Gunung Agung (Artanti, 2017). Hal ini berarti masyarakat di Desa Selat perlu dibekali dengan pengetahuan dan ketrampilan dalam menghadapi bencana.

Setiap Desa di Bali, memiliki satuan penjaga keamaan yang disebut sebagai Pecalang. Secara umum tugas Pecalang seperti tugas polisi yang mengatur lalu lintas di areal kegiatan upacara keagamaan dengan berkoordinasi dengan polisi dan turut serta menjaga keamanan masyarakat serta menyampaikan isu-isu Kamtibmas. Sebagai penjaga keamanan masyarakat, Pecalang tentunya harus dibekali pelatihan siap siaga bencana sebagai upaya dalam meminimalkan korban baik korban jiwa ataupun korban harta. Berdasarkan data dan fakta yang dilihat ketika melakukan survey dan diskusi bersama dengan perangkat Desa Selat, maka ditemukan beberapa permasalahan dalam mendukung program Desa Tangguh Bencana yaitu masyarakat desa Selat khususnya para belum terpapar konsep manajemen bencana dan belum pernah mendapatkan pelatihan Bantuan Hidup Dasar (BHD).

Oleh karena itu, perlu diaadakan suatu pelatihan sebagai salah satu pemberdayaan masyarakat dalam meningkatkan kesiapsiagaan sekaligus mendukung berdirinya desa tangguh bencana pada Pecalang di Desa Selat, Badung.

\section{METODE}

Pelatihan ini merupakan jenis pengabdian masyarakat dengan menggunakan pendekatan kuantitatif untuk mengukur tingkat kesiapan dan pengetahuan peserta dalam menghadapi bencana di Badung dengan menggunakan desain penelitian quasi-experiment yaitu "One Groups Pretest-Posttest Design", yaitu desain penelitian yang terdapat pretest sebelum diberi perlakuan dan posttest setelah diberi perlakuan. Penelitian ini menggunakan teknik total sampling terhadap 25 orang pecalang di desa Selat, Kabupaten Badung. Pecalang adalah satuan unit keamanan Desa yang memiliki tugas 
seperti tugas polisi yang mengatur lalu lintas di areal kegiatan upacara keagamaan dengan berkoordinasi dengan polisi dan turut serta menjaga keamanan masyarakat serta menyampaikan isu-isu Kamtibmas. Sebagai penjaga keamanan masyarakat, Pecalang tentunya harus dibekali pelatihan siap siaga bencana sebagai upaya dalam meminimalkan korban baik korban jiwa ataupun korban harta.

Peserta diberikan pelatihan "Siap Siaga Bencana (SIGANA)" selama 5 hari dari tanggal 17 April 2018 sampai dengan 21 April 2018. Pre test dilakukan di awal pertemuan pada tanggal 17 April 2018 dan post test dilakukan saat penutupan pelatihan yaitu 21 April 2018 setelah semua materi dan simulasi diberikan seperti dalam TABE 1 BERIKUT. Pre-test dan post-test yang diberikan menggunakan alat ukur kesiapsiagaan oleh LIPI dan UNESCO/ISDR versi revisi tahun 2011 yang terdiri dari pengetahuan tentang bencana (KAP), kesiapsiagaan untuk keadaan darurat (EP), peringatan bencana (WS) dan mobilisasi sumber daya (RMC) dengan indikator penilaian kesiapsiagaan tinggi apabila total skor 80-100, kesiapsiagaan sedang apabila skor 60-80, dan kesiapsiagaan rendah apablia skor $<60$ (Hidayati, dkk., 2011).

\section{HASIL DAN PEMBAHASAN}

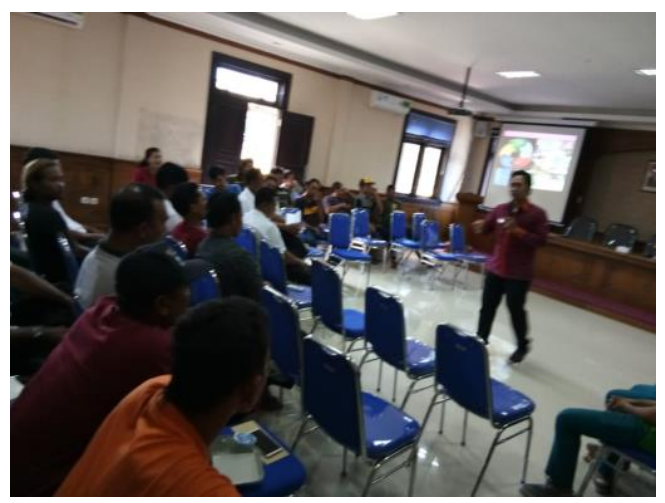

Gambar 1. Pelatihan Hari Pertama Manajemen Bencana

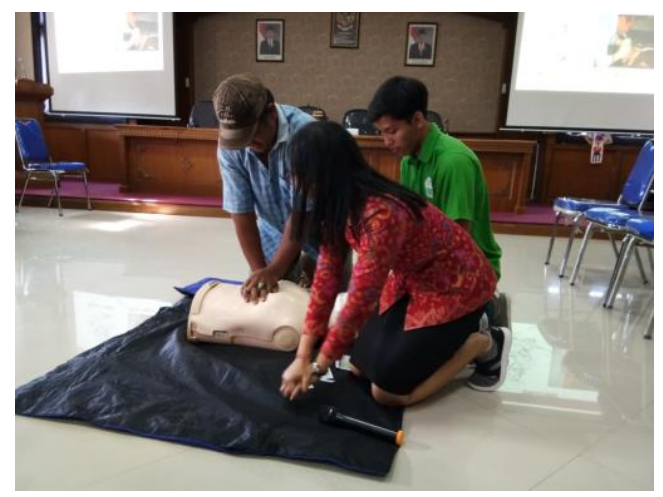

Gambar 2. Pelatihan Hari Keempat Simulasi BHD

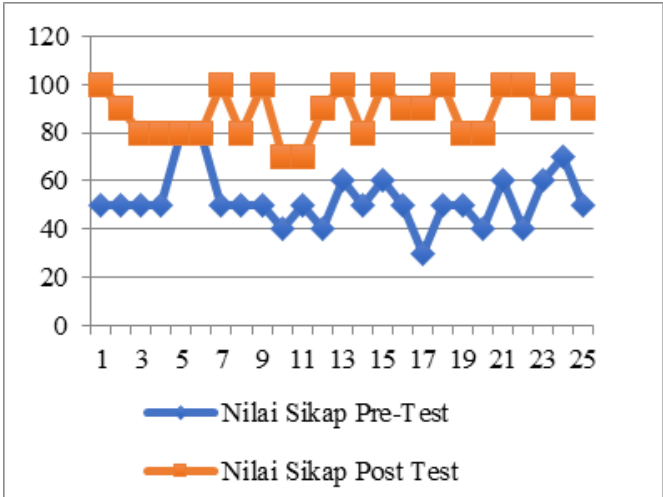

Gambar 3. Grafik Perbandingan Kesiapsiagaan Sebelum dan Setelah Pelatihan SIGANA

Gambar 3 menunjukkan bahwa terjadi peningkatan nilai kesiapsiagaan setelah peserta mengikuti pelatihan SIGANA. Nilai sikap tertinggi sebelum diberikan pelatihan adalah 80 dan terendah adalah 30 , sedangkan setelah diberikan pelatihan nilai sikap tertinggi adalah 100 dan terendah pada skor 70. Akan tetapi, gambar 2 juga memperlihatkan adanya nilai sikap yang tidak berubah pada 6 orang peserta, dimana sebelum dan sesudah pelatihan mendapatkan skor 80 .

Tabel 2. Perbedaan Kesiapsiagaan Sebelum dan Setelah Pelatihan SIGANA

\begin{tabular}{ccccc}
\hline & $\begin{array}{c}\text { Mean } \\
\end{array}$ & $\Delta$ Mean & t & p \\
& \pm SD & \pm SD & & \\
\hline Pre- & 46.40 & - & 31.423 & $<0.001$ \\
Test & \pm & $48.00 \pm$ & & \\
& 9.522 & 7.638 & & \\
\cline { 1 - 2 } Post- & 94.40 & & & \\
Test & \pm 8.206 & & & \\
\hline
\end{tabular}

Berdasarkan analisis data menggunakan paired T-test nilai pre-test dan post-test kesiapsiagaan pada 25 orang peserta pelatihan SIGANA didapatkan perbedaan yang signifikan 
dengan nilai $\mathrm{p}<0.001$. Hal ini menunjukkan bahwa materi pelatihan yang disampaikan telah dapat terserap dengan baik oleh masing-masing peserta pelatihan, dengan adanya pengetahuan yang cukup, maka terjadi perubahan sikap kesiapsiagaan pada peserta pelatihan SIGANA.

Tabel 2 diatas juga meunjukkan bahwa nilai rata-rata kesiapsiagaan peserta pelatihan sebelum mengikuti pelatihan SIGANA adalah 46.40 yang artinya tergolong dalam kategori kesiapsiagaan rendah. Sedangkan pada hasil post-test, nilai rata-rata kesiapsiagaan peserta naik hingga 94.40 yang artinya termasuk dalam kategori kesiapsiagaan tinggi.

Kesiapsiagaan pada pasal 1 angka $7 \mathrm{UU}$ Nomor 24 Tahun 2007 Tentang Penanggulangan

Pelatihan SIGANA terdiri dari pemberian materi manajemen bencana termasuk pengantar bencana, perencanaan, mitigasi, siap siaga bencana, peringatan bencana dan mobilisasi sumber daya, simulasi table top disaster, dan simulasi Bantuan Hidup Dasar (BHD).

Notoatmodjo (2012) menyatakan pengetahuan adalah informasi yang diketahui atau disadari oleh seseorang yang muncul ketika seseorang menggunakan indera atau akal budinya untuk mengenali benda atau kejadian tertentu yang belum pernah dilihat atau dirasakan sebelumnya. Menurut Daud, dkk. (2014), pengetahuan dan sikap tidak dapat dipisahkan. Kedua hal tersebut saling berhubungan, dengan adanya pengetahuan tentang kesiapsiagaan bencana maka akan mempengaruhi sikap seseorang saat terjadi bencana.

Pengetahuan yang tidak menekankan pada pengalaman biasanya mudah terlupakan, akan tetapi dengan simulasi table top disaster dan BHD yang diberikan dalam pelatihan SIGANA dapat membuat peserta pelatihan tidak mudah lupa dengan pengetahuan manajemen bencana yang didapatkan serta mempengaruhi kesiapsiagaan peserta ketika dihadapkan pada bencana.

Sebuah penelitian dari Addianto, Yueniwati dan Fathoni (2016), menemukan bahwa latihan dengan table top disaster pada mahasiswa keperawatan mampu meningkatkan pengetahuan responden tentang kesiapsiagaan bencana dan peran pada fase tanggap darurat mencapai 7375\% dan peningkatan level kesadaran serta kesediaan dalam berpartisipasi dalam tanggap darurat bencana sebesar $85 \%$. Hal ini membuktikan bahwa metode pembelajaran
Bencana, didefinisikan sebagai serangkaian kegiatan yang dilakukan untuk mengantisipasi bencana melalui pengorganisasian serta melalui langkah yang tepat guna dan berdaya guna. Peningkatan level kesiapsiagaan bencana ini juga mencerminkan keberhasilan pelatihan SIGANA yang telah dilaksanakan. Hal ini sejalan dengan Pratiwi dan Prihatiningsih (2016) dengan hasil penelitian adalah terdapat pengaruh pelatihan penanggulangan bencana gempa bumi untuk meningkatkan kesiapsiagaan.

Pelatihan SIGANA merupakan pelatihan yang bertujuan untuk meningkatkan kesiapsiagaan bencana masyarakat yang tidak hanya terdiri dari metode ceramah saja.

dengan table top merupakan sebuah metode baru yang menyenangkan dan efektif dalam meningkatkan pengetahuan dan sikap.

Akan tetapi factor pengetahuan yang didapatkan dari pelatihan bukan menjadi satusatunya factor yang mempengaruhi sikap kesiapsiagaan seseorang akan terjadinya bencana. Terdapat beberapa factor lainnya yang dapat mempengaruhi kesiapsiagaan masyarakat seperti pengalaman sebelumnya. Hal ini diperkuat dengan hasil penelitian Havwina, Maryani dan Nandi (2016), bahwa bahwa pengalaman mempengaruhi kesiapsiagaan peserta didik secara signifikan dengan koefisien yang bernilai positif yang berarti bahwa sehingga semakin tinggi nilai variabel pengalaman bencana maka kesiapsiagaan semakin baik pula.

Faktor pengalaman inilah yang menjadi keterbatasan penerapan pelatihan SIGANA dalam meningkatkan kesiapsiagaan bencana pada pecalang di Desa Selat Badung, karena belum dilaksanakannya simulasi dengan setting yang menyerupai bencana sessungguhnya. Oleh karena itu, untuk pelatihan selanjutnya dapat menambahkan metode simulasi dengan bermain peran yang sekaligus melibatkan BNPB.

\section{SIMPULAN DAN SARAN}

Berdasarkan pembahasan di atas maka dapat disimpulkan bahwa pelatihan SIGANA efektif dalam meningkatkan kesiapsiagaan bencana pada pecalang Desa Selat, Badung. Oleh karena itu, untuk mendukung berdirinya Desa Tangguh Bencana, perlu dilakukan pelatihan-pelatihan 
kebencanaan yang rutin hingga mencapai seluruh lapisan masyarakat.

\section{DAFTAR RUJUKAN}

Addianto, Yueniwati dan Fathoni (2016). Pengaruh Pembelajaran Tabletop Disaster Exercise (TDE) Terhadap Pengetahuan Mahasiswa S1 Keperawatan Dalam Memberikan Penatalaksanaan Korban Pada Simulasi Tanggap Darurat Bencana. Jurnal Ilmiah Kesehatan Rustida, 3 (1).

Artanti, A. A. (2017). Pertamina: Suplai BBMElpiji di Wilayah Gunung Agung Aman. Medcom.id (online)

di https://www.medcom.id/ekonomi/energi/G bm6x99k-pertamina-suplai-bbm-elpiji-diwilayah-gunung-agung-aman (diakses 10 Maret 2018)

BNPB. (2013). IRBI (Indeks Risiko Bencana Indonesia). Jakarta: Badan Nasional Penanggulangan Bencana.

Daud, R. S, Milfayetty, S. \& Dirhamsyah, M. (2014). Penerapan Pelatihan Siaga Bencana dalam Meningkatkan Pengetahuan, Sikap dan Tindakan Komunitas SMA Negeri 5 Banda Aceh. (Tesis) Universitas Syiah Kuala.

Havwina, T., Maryani, E., \& Nandi (2016). Pengaruh Pengalaman Bencana Terhadap Kesiapsiagaan Peserta Didik Dalam Menghadapi Ancaman Gempabumi Dan Tsunami. Jurnal Pendidikan Geografi, 16 (2).

Hidayati, D., Widayatun, Hartana, P., Triyono, Kusumawati, T. (2011). Panduan Mengukur Tingkat Kesiapsiagaan Masyarakat Dan Komunitas Sekolah. Jakarta: LIPI Press.

Indriasari, F. N. (2016). Pengaruh Pemberian Metode Simulasi Siaga Bencana Gempa Bumi Terhadap Kesiapsiagaan Anak Di Yogyakarta. Jurnal Keperawatan Soedirman, 11 (3).

Notoatmodjo, S. (2012). Promosi Kesehatan Teori dan Aplikasi. Jakarta : PT Rineka Cipta
Pratiwi, E. \& Prihatiningsih, D. (2016). Pengaruh Pelatihan Penanggulangan Bencana Gempa Bumi Terhadap Kesiapsiagaan Palang Merah Remaja (PMR) SMAN 1 Pleret Bantul Dalam Menghadapi Bencana. (Tesis) Universitas 'Aisyiyah Yogyakarta

UU Nomor 24 Tahun 2007 Tentang Penanggulangan Bencana 